\title{
ANALISA FAKTOR YANG MEMPENGARUHI HAKIM DALAM MENETAPKAN HUKUMAN PIDANA BAGI PENGGUNA NARKOBA DI BAWAH UMUR
}

\author{
Derry Angling Kesuma \\ Sumpah Pemuda School of Law (STIHPADA) Palembang, Indonesia \\ Email: kesumaderry@gmail.com
}

\begin{abstract}
Abstrak
Kasus penyalahgunaan narkoba dikalangan remaja menunjukan angka yang terus meningkat, kasus yang ditangani pengadilanpun beragam. Fokus penelitian ini adalah menganlisa berbagai faktor yang mempengaruhi hakim untuk menetapkan hukuman bagi penyalahguna narkoba yang masih di bawah umur. Penelitian ini adalah penelitian kualitatif dengan pendekatan yusridis-normatif. Data yang digunakan berupa data sekunder. Data dikumpulkan melalui wawancara dan kajian pustaka, total responden dalam penelitian ini berjumlah 10 orang hakim pengadilan yang pernah menangani kasus penyalahgunaan narkoba yang dilakukan oleh anak di bawah umur. Dari hasil analisis penelitian, dapat disimpulkan bahwa dalam memutuskan vonis kasus penyalahgunaan narkoba pelaku di bawah umur hakim dipengaruhi oleh berbagai faktor, diantaranya adalah: pengaruh politik, pengaruh penegakan hukum; dan pengaruh opini publik dan media.
\end{abstract}

Kata Kunci: Penyalahgunaan Narkoba, Hakim, Pengadilan, Pengaruh.

\begin{abstract}
Drug cases among teenagers show an increasing number, the cases handled by the courts are varied. This study is to analyze various factors that influence judges to determine the focus of punishment for drug abusers who are underage. This research is a qualitative research with a juridical-normative approach. The data used in the form of secondary data. Data were collected through interviews and literature study, the number of respondents in this study revealed 10 court judges who had handled drug cases committed by minors. From the results of research analysis, what is said that in deciding drug cases is under assessment by various factors, including: political influence, effect of law enforcement, and influence of public opinion and media.
\end{abstract}

Keywords: Drug Abuse, Judge, Court, Influence.

\section{A. PENDAHULUAN}

Di era globalisasi yang sangat terbuka ini, seluruh komponen bangsa dituntut untuk memberikan perhatian yang sangat besar kepada generasi-generasi muda, sebisa mungkin menjauhkan mereka dari hal yang negatif dan berdampak panjang bagi generasi selanjutnya (Azriful, Ibrahim \& Sulaiman, 2016). Salah satu pengaruh negatif tersebut adalah penggunaan narkoba pada generasi muda. Penggunaan narkoba telah dianggap sebagai 
kejahatan lintas negara, termasuk di Indonesia. Sebagai salah satu negara kepulauan terbesar di dunia, Indonesia cenderung menghadapi risiko yang lebih besar karena lokasinya yang strategis di Asia Tenggara, sehingga menyebabkan tingginya angka lalu lintas transaksi obat domestik dan internasional (Handayani, 2018). Mengingat Indonesia merupakan salah satu negara penandatangan konvensi Perserikatan Bangsa-Bangsa (PBB) tentang narkotika, maka pemerintah Indonesia telah berupaya memberantas tindak pidana tersebut melalui UndangUndang Nomor 35 Tahun 2009 tentang Narkotika (selanjutnya disebut Undang-Undang Narkotika Indonesia).

Anak-anak/remaja yang masih di bawah umur dengan praduga tidak bersalah menjadi sasaran para pengedar narkoba dalam memperluas pasarnya karena biasanya polisi tidak mencurigai mereka (Hapsari, Soponyono \& Sularto, 2016). Tidak seperti orang dewasa yang dijerat dengan hukuman berat seperti penjara atau hukuman mati ketika tertangkap, anak di bawah umur ditempatkan di bawah pengawasan ketat orang tua/wali atau dikirim ke pusat rehabilitasi (Gifford, Elder, Sloan \& Evans, 2016). Anak-anak yang terlibat dalam penjualan dan perdagangan narkoba sulit dilacak dan diidentifikasi karena sifat perdagangannya yang ilegal dan tersembunyi (Kanang, 2017). Selain itu, karena munculnya fenomena tersebut belakangan ini, ada beberapa hal yang perlu dipahami yaitu: (1) karakteristik anak/remaja yang terlibat dalam penyalahgunaan, penjualan, dan perdagangan narkoba; (2) pola rekruitmen ke dalam jaringan narkoba dan strategi/teknik yang digunakan untuk membuat anak terjerat dalam jaringan narkoba/narkoba; dan (3) strategi/teknik untuk mencegah mereka bergabung dan/atau merehabilitasi mereka dari jaringan narkoba dan menjadi hal yang patut mendapat perhatian dari pemerintah, lembaga pendidikan, dan jaringan sosial di komunitas dan masyarakatnya (Zahra \& Sularto, 2017).

Secara umum, pasokan narkoba berasal dari negara Asia tenggara, yang selanjutnya diproduksi atau diselundupkan ke dalam negeri. Seperti disebutkan sebelumnya, narkoba yang paling umum digunakan adalah yang berbahan dasar metamfetamin seperti pil dan sabu (methamphetamine chloride) yang paling banyak ditemukan di Jakarta. Obat-obatan ini sering digunakan dalam kombinasi dengan ganja, amfetamin, dan zat yang mudah menguap seperti lem dan pengencer cat. Demikian pula, hingga kini Indonesia masih menjadi tempat transit narkoba yang berasal dari The Golden Triangle dan China menuju Australia (Sukoco, 2011). Pasokan narkoba di Indonesia sebagian besar berasal dari negara lain (Maluccio \& Ainsworth, 2003). Namun, seperti halnya negara di Asian Tenggara, semisal Filipina dan Thailand, terjadi pergeseran pola pasokan di Indonesia. Meski sebagian besar pasokan narkoba masih diimpor, baru-baru ini investigasi yang dilakukan Polisi telah mengungkap sejumlah pabrik ekstasi. Perlahan, Indonesia juga mulai memproduksi obat lokal dalam skala yang semakin luas (Nainggolan, Zahara \& Saparuddin, 2010).

Dalam hukum positif di Indonesia, lembaga peradilan tidak menciptakan preseden hukum tetapi tetap terlibat dalam penafsiran aturan hukum tertulis, lembaga peradilan dapat dianggap terikat oleh asas legalitas, yang dapat membatasi praktik diskresi (Novitasari, 2017). Misalnya, pelanggaran narkoba tercantum dalam hukum pidana yang mengharuskan pengadilan untuk mengikuti dan menerapkan aturan yang telah berlaku (Sepud, 2017). Sebaliknya, common law memberikan lebih banyak kesempatan bagi hakim untuk menyusun hukuman bagi terpidana, tetapi sebagai hasilnya, pengadilan mungkin perlu mengikuti pedoman hukuman untuk menghindari pandangan subyektif yang tidak adil (Simmons \& 
Dunker, 2010). Dalam budaya common law, penerapan aturan hukum dilaksanakan melalui praktik hukuman. Namun, di Indonesia variasi vonis dalam tetapan pengadilan masih terjadi karena perbedaan budaya atas pertimbangan yudisial tentang penerapan aturan hukum saat menghukum pelanggar narkoba, terutama karena faktor usia terdakwa (Soponyono, 2016).

Secara umum, pembentukan suatu hukum dilakukan oleh pembentuk UU, maka penegak hukum dimungkinkan juga membentuk suatu hukum, kemudian dapat dijadikan rujukan yang menjadi pedoman bagi penegak hukum secara khusus dan masyarakat secara umum (Stone, 2018). Putusan ini mengandung asas-asas hukum yang dirumuskan dalam suatu peristiwa yang konkret, tetapi memiliki suatu kekuatan yang berlaku secara umum. Dalam hukum, suatu putusan dapat sekaligus mengandung dua buah unsur, yaitu: 1) Putusan merupakan penyelesaian suatu peristiwa yang konkret; dan 2) Putusan merupakan suatu auran hukum yang berlaku untuk masa depan. Hal ini biasa disebut sebagai konkritisasi serta individualisasi peraturan umum yang bersifat abstrak dalam sebuah peristiwa yang konkret (Wahyuningsih, Khomsan \& Ekawidyani, 2014). Suatu sistem peradilan pidana akan menjadi perangkat hukum dalam menyelesaikan berbagai bentuk kriminal dalam masyarakat yang dianggap sebagai sebuah respon penyelesaian masalah kriminal dan sebagai wujud usaha penegakan hukum.

\section{B. METODE}

Penelitian ini adalah penelitian kualitatif dengan pendekatan yusridis-normatif. Data yang digunakan berupa data sekunder. Fokus penelitian ini mengkaji faktor-faktor penyebab utama yang dianggap hakim mempengaruhi keputusan hukuman mereka. Tanpa mempertimbangkan faktor-faktor situasional yang mempengaruhi pemidanaan, keputusan tidak bisa dianggap objektif. Oleh karena itu, perlu diketahui berbagai faktor yang dipertimbangkan oleh hakim ketika menjatuhkan hukuman kepada pelaku tindak penyalahgunaan narkoba di bawah umur. Data dikumpulkan melalui wawancara dan studi pustaka, total responden dalam penelitian ini berjumlah 10 orang hakim pengadilan yang pernah menangani kasus penyalahgunaan narkoba yang dilakukan oleh anak di bawah umur.

\section{HASIL DAN PEMBAHASAN}

Menurut data dari BNN, setiap tahun para pemakai di Indonesia dapat menghabiskan uang sebesar Rp. 72 Triliun untuk mengkonsumsi narkoba. Sejak sepuluh tahun terakhir, pengguna narkoba terus meningkat, dan Indonesia kini dalam keadaan 'kondisi darurat narkoba'. Namun kabar baiknya, angka prevalensi penyalahgunaan narkoba pada remaja menunjukan tren yang terus menurun. Seperti yang disajikan dalam tabel di bawah ini:

\section{Tabel 1. Angka Prevalansi Penyalahgunaan Narkoba}

\begin{tabular}{|c|c|c|}
\hline $\begin{array}{c}\text { Pernah } \\
\text { Pakai }\end{array}$ & Tahun & $\begin{array}{c}\text { Pakai Setahun } \\
\text { Terakhir }\end{array}$ \\
\hline $\mathbf{8 , 2 0 \%}$ & 2007 & $5,21 \%$ \\
\hline $\mathbf{7 , 8 1 \%}$ & 2010 & $5,11 \%$ \\
\hline $\mathbf{4 , 3 2 \%}$ & 2013 & $2,97 \%$ \\
\hline $\mathbf{3 , 8 1 \%}$ & 2017 & $1,95 \%$ \\
\hline
\end{tabular}

Sumber: Badan Narkotika Nasional (2018) 
Angka tersebut tentu menjadi kabar baik, pada 2007 angkanya 8,20\% dan menurut menjadi 7,81\% pada 3 tahun setelahnya. Meskipun demikian, akan tetapi tren kasus maupun tersangka narkoba terus meningkat. Data dari Polri dan BNN menyebutkan angka kasus pada tahun 2010 mencapai 26.686 dan terus meningkat pada 2017 menjadi 28.897 kasus, kasus tersebut mengalami peningkatan signifikan pada pengguna bahan adiktif lain: dari 16.886 kasus pada rentang 2014-2015, menjadi 23.518 kasus. Data tersebut disajikan dalam tabel 2 berikut ini:

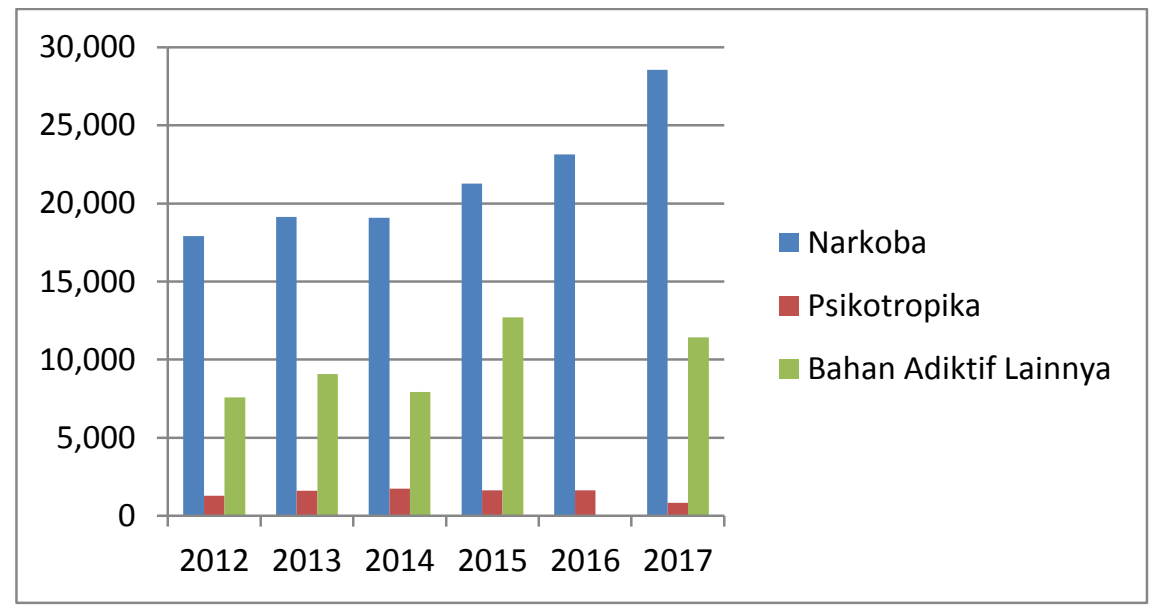

Gambar 1. Kasus Penggunaan Narkoba (2012-2017)

Sumber: Polri dan BNN

Pada kasus bahan adiktif lainnnya, jumlah tersangka tertinggi terjadi pada 2015 yaitu sebanyak 13.355 orang atau naik 61,53\% dari tahun sebelmnya (8.270 orang). Dari data tersebut tentu saja banyak pelaku penyalahgunaan narkoba dari kalangan pelajar seperti data pada tabel 1 yang dikumpulkan melalui kuisioner kepada pelajar atau mahasiswa. Minimnya anggaran negara untuk penanganan menyebabkan kasus penyalahgunaan narkoba pada anakanak di bawah umur tidak tertangani, sehingga seringkali harus menyeret para pelaku ke ranah hukum.

Prinsip dalam sistem peradilan pidana anak diatur dalam konvensi internasional serta hukum peraturan perundang-undangan, sebagai contoh hal ini di atur dalam: 1) UUD 1945 Pasal 34; 2) UU RI No. 4 Tahun 1979 tentang Kesejahteraan Anak; 3) UU RI No. 5 Tahun 1979 Tentang Kejaksaan Republik Indonesia; 4) UU No. 39 Tahun 1999 tentang HAM; 5) UU No. 23 Tahun 2002 tentang Perlindungan Anak; dan 6) UU No. 3 Tahun 1997 tentang Pengadilan Anak. Perlindungan hukum terhadap pelaku penyalahgunaan narkotika secara umum terletak pada keterangan saksi dalam peradilan, kemudian pada sanksi hukum peradilan berdasarkan UU No. 35 Tahun 2009 tentang narkotika, serta adanya rehabilitasi bagi terdakwa.

Dalam UU No. 37 tahun 1997 terdapat berbagai ketentuan mengenai bentuk perlindungan hukum pada terdakwa penyalahgunaan narkoba di bawah umur, diantaranya adalah: 1) Pembatasan Umur Anak. Jika anak melakukan tindak pidana pada usia 14-17 tahun, maka terdakwa tetap menjalankan proses sidang pengadilan; 2) Ditangani oleh Pejabat Khusus. Pejabat khusus yang dimaksud yaitu pejabat yang telah memperoleh sertfikasi sebagai syarat guna melakuklan pemeriksaan terdakwa, penyidik, penuntut serta hakim; 3) Pemeriksaan pengadilan berada dalam suasana kekeluargaan. Dalam ketentuan UU No. 3 tahun 1997 Pengadilan Anak dalam pasal 1 angka (5), (6), dan (7) para pejabat pemeriksa 
(hakim, penuntut umum, serta penasihat hukum) tidak menggunakan pakaian dinas, tetapi pejabat pemeriksa menggunakan pakaian batik. Begitu juga dengan panitera tidak diperkenankan memakai jas dalam pengadilan; 4) Sidang terututup; 5) Bersidang dengan hakim tunggal, yaitu perkara terdakwa penyalahgunaan narkoba di bawah umur di ancam dengan pidana 5 tahun ke bawah; 6) Laporan pembimbing kemasyarakatan (balai pemasyarakatan di wilayah hukum Pengadilan Negeri tempat perkara). Laporan ini dibacakan oleh hakim sebelum vonis dijatuhkan; 7) Penahanan anak lebih singkat dari orang dewasa. Hal ini sesuai dengan UU no. 3 tahun 1997 tentang Pengadilan Anak misalnya pada pasal 26, terdakwa di bawah umur dikenakan seperdua dari ancaman pidana penjara ynag diberlakukan kepada orang dewasa, jika di jatuhkan hukuman mati atau penjara seumur hidup, maka anak dapat dijatuhkan hukuman maksimal sepuluh tahun. Jika terdakwa belum mencapai usia 12 tahun, maka hanya akan dikembalikan kepada negara untuk mendapat rehabilitasi serta pendidikan; 8) Terdakwa didampingi oleh orangtua wali atau orangtua asuh, pembimbing kemasyarakatan dan penasihat hukum; dan 9) Saksi dapat didengar tanpa dihadiri oleh terdakwa.

\section{Pengaruh Politik}

Keinginan para pejabat politik untuk menekan angka penyalahgunaan narkoba menciptakan ketegangan antara melayani agenda politik pemerintah dan mencari keadilan bagi terdakwa. Kekhawatiran yudisial terhadap pernyataan Kepala BNN baru-baru ini, yang menyatakan 'perang terhadap narkoba', muncul sebagai tanggapan MK terhadap perang terhadap narkoba. Hakim Pengadilan merasa prihatin dengan suasana hukuman perang terhadap narkoba yang tampaknya memberikan tekanan pada hakim untuk menghukum pelanggar narkoba di bawah umur. Suasana hukuman ini dapat memberikan tekanan pada kebijaksanaan para hakim pengadil. Hakim Pengadilan yang berpartisipasi menganggap tidak mungkin untuk menghukum setiap pelaku narkoba atau membebaskan pelaku narkoba di bawah umur tanpa dukungan politik karena hal ini dapat meningkatkan pelanggaran hak-hak sipil dan masalah kemanusiaan.

Tampaknya juga ada kebingungan aparat di kantor peradilan pidana (termasuk polisi, BNN, kejaksaan, dan hakim) mengenai tanggapan kasus penggunaan narkoba. Misalnya, Hakim 6 prihatin dengan tindakan yang tidak adil dalam menangkap, menuntut, dan memenjarakan mereka yang dianggap oleh Hakim 6 tidak melakukan kejahatan (yaitu, pengguna narkoba di bawah umur). Hakim 9 juga menganggap bahwa tidak ada manfaat dari hukuman yang keras kepada pelaku penyalahgunaan narkoba di bawah umur dalam agenda 'perang terhadap narkoba' ini. Hukuman berat dalam agenda 'perang terhadap narkoba' dipandang berdampak negatif pada keadilan, sebagaimana dinyatakan oleh Hakim 8, “... Terlalu lama dalam penahanan menyebabkan efek negatif, karena pelaku berbaur dengan pengedar narkoba yang lebih berbahaya, hal ini sangat berdampak buruk terutama bagi aspek psikologis anak...".

Hakim 8 menilai, setelah pengguna narkoba masuk penjara, kondisinya akan lebih parah. Di Pengadilam, ketika mempertimbangkan efek negatif dari pemenjaraan, Hakim 5 menggambarkan bahwa para pelanggar mengalami kerugian dari hukuman agenda 'perang melawan narkoba' yang digalakan oleh pemerintah. Hakim 5 menjelaskan bahwa ketika pelaku di bawah umur menghabiskan tujuh bulan penjara, mereka akan mengalami 
pengalaman traumatis: "Saya melihat bahwa bagi orang-orang dengan masalah penggunaan narkoba, hukuman penjara tidak efektif karena ketika saya melihat kondisi mereka selama enam sampai tujuh bulan di penjara, dia mengalami trauma yang berdampak sangat panjang bagi hidupnya" (Hakim 5).

Dari kutipan yang disajikan pada bagian ini, dapat disimpulkan bahwa hukuman penjara bagi pengguna narkoba dirasakan sebagai kerugian bagi terdakwa. Beberapa melaporkan kerugian bagi pelaku, Negara, dan masyarakat yang lebih luas dari hukuman penjara pelanggar penyalahgunaan narkoba di bawah umur. Misalnya, Hakim 3 mengatakan, "Mengenai keadilan sosial, saya masih skeptis tentang manfaat proses hukum penyidikan dan pemidanaan...tidak ada manfaat bagi negara, bagi pelaku, dan bagi masyarakat" (Hakim 3). Berbeda dengan pernyataan sebelumnya, justru Hakim 4 menyatakan: "Beberapa dari mereka bergabung dengan sindikat narkoba di dalam penjara, dan entah bagaimana tidak ada efek jera. Beberapa dari mereka masih bisa menguasai pasar narkoba di dalam lapas... Memang, berurusan dengan narkotika itu sulit" (Hakim 4). Penjelasan Hakim 3 dan Hakim 4 menunjukkan kerugian dari memenjarakan pelaku narkoba di bawah umur di pengadilan Indonesia saat ini, yang terutama merupakan saluran pengedar.

\section{Pengaruh Penegakan Hukum}

Bagaimana polisi mengatur kasus ini mempengaruhi interpretasi yudisial. Hal tersebut dapat dilihat dalam penargetan selektif polisi terhadap individu-individu dari latar belakang sipil dengan strata sosial rendah. Penargetan selektif ini diungkapkan oleh Hakim 7 , yang mengungkapkan alasan keprihatinannya sebagai berikut: 'Ada kebutuhan akan kredibilitas selama proses penyelidikan, penuntutan, dan sidang pengadilan; ini berarti penyidikan polisi tidak boleh secara selektif menargetkan terdakwa dengan strata sosial tertentu' (Hakim 7).

Dari keterangannya, Hakim 7 tampak prihatin dengan kecenderungan polisi yang selektif dalam mengusut kasus narkoba menimbulkan persoalan kredibilitas dalam proses penyidikan. Penargetan selektif ini menunjukkan bahwa keadilan dalam hukum Indonesia adalah bersyarat- yang tergantung pada polisi yang mengatur kasus tersebut. Isu penargetan selektif menyebabkan para hakim harus melakukan upaya ekstra di Pengadilan untuk menafsirkan fakta-fakta dari kasus tersebut. Penafsiran yudisial ini terlihat jelas dalam upaya para hakim peserta untuk mendefinisikan kembali siapa yang bisa menjadi saksi dalam kasus narkoba. Bagaimana polisi bertindak sebagai saksi ditafsirkan oleh sebagian besar peserta sebagai kendala dalam menjatuhkan hukuman. Penafsiran ini karena polisi sering membuat pernyataan yang kontradiktif, misalnya komentar Hakim 9: “...Kedua polisi yang menjadi saksi di pengadilan yang pernah saya adili, membuat pernyataan kontradiktif... kesaksian kontradiktif itu menyadarkan saya bahwa dalam kasus narkoba. peran polisi seharusnya sebagai penyidik, bukan sebagai saksi, yang dapat ditemukan adanya alibi dari saksi. Atas dasar itu, saya menolak kasus terhadap terdakwa, dan Mahkamah Agung menyetujui putusan saya... (Hakim 9)

Bagaimana penegakan hukum mengatur kasus juag dapat mempengaruhi rehabilitasi pelanggar narkoba anak. Pengaruh ini karena pada awal tahap penyidikan, vonis untuk mengalihkan pengguna narkoba ke rehabilitasi ada di tangan polisi. Dengan demikian, kesediaan polisi untuk mengubah praktiknya di awal tahap penyidikan akan berdampak pada 
rehabilitasi pelaku narkoba di bawah umur. Selain itu, wawancara dengan para hakim Pengadilan yang menjadi responden menunjukkan interpretasi fakta, dan mereka tidak ragu untuk memutuskan pemberhentian pada besar kasus yang ditangani. Meskipun polisi dapat mengatur kasus ini, mereka bukan orang yang memutuskan hukuman, dan oleh karena itu hasil hukuman mungkin berbeda.

Bukti untuk penargetan selektif ini adalah bahwa individu dari latar belakang ekonomi rendah lebih sering diselidiki daripada individu dari latar belakang ekonomi yang lebih baik. Penargetan selektif ini menyebabkan sebagian kecil hakim yang menjadi responden harus menafsirkan kembali fakta-fakta kasus dan membedakan antara korban keadaan dan pelaku. Penargetan selektif ini juga mempengaruhi penyajian bukti yang selektif di ruang sidang. Penyajian bukti oleh penuntut sering kali sulit karena ditemukan setelah sidang pengadilan bahwa para pelanggar didakwa dengan hukuman secara berbeda dari yang seharusnya. Misalnya, untuk narkoba dalam jumlah yang lebih kecil, terdakwa sering dituntut dengan berat, sedangkan untuk obat-obatan dalam jumlah yang lebih besar, terdakwa sering dituntut dengan ringan. Untuk mempertimbangkan apakah tindakan menafsirkan fakta dan hukum yang relevan akan mencapai keadilan sosial yang lebih luas sebagian tergantung pada publik dan media.

Interpretasi yudisial dari fakta-fakta kasus dengan mempertimbangkan berbagai perspektif (yaitu dari meninjau laporan yang berbeda, bukti dan pengamatan yudisial) sebelum sampai pada hukuman. Namun, interpretasi yudisial atas fakta-fakta kasus menjadi tantangan karena polisi sering melakukan penilaian terhadap masalah penggunaan narkoba. Penilaian selektif ini menyebabkan beberapa hakim melakukan upaya ekstra di Pengadilan sampel untuk menetapkan fakta-fakta kasus, seperti yang diungkapkan Hakim 8: "Dalam praktiknya, hanya beberapa penilaian yang dilakukan. Sembilan dari sepuluh kasus narkoba tidak disertai tes urine. Ketiadaan penilaian ini menimbulkan tantangan bagi hakim, khususnya; dalam membedakan antara korban dan pelaku... hakim harus melakukan upaya ekstra di Pengadilan sampel untuk menemukan fakta" (Hakim 8)

Kutipan di atas menyoroti Hakim 8 supaya melakukan upaya ekstra di Pengadilan untuk menetapkan fakta kasus dan membedakan antara pelaku yang menjadi korban keadaan mereka dan pelaku yang sebenarnya. Sebagaimana diungkapkan oleh Hakim 3 misalnya, menyebutkan: "Faktanya, kita perlu memeriksa apakah urin itu positif [untuk indikasi penggunaan narkoba]. Menurut pendapat saya, kita dapat mempertimbangkan pelaku ditangkap melalui penggunaan dan setelah pelaku baru saja selesai menggunakannya. Biasanya, petugas polisi enggan memeriksa urin pelaku. Itulah realita dalam penyidikan!'” (Hakim 3)

Kutipan di atas menunjukan keprihatinan Hakim 3 tentang tantangan untuk menetapkan fakta-fakta kasus karena petugas polisi gagal untuk memeriksa urin pelaku. Faktor lain yang menantang penegakan keadilan tampaknya berasal dari pembuktian jaksa. Dalam wawancara berikut, dua hakim MK mengungkapkan keprihatinannya terhadap praktik diskriminatif jaksa: "Kadang kita tidak mengerti, dan pelaku sering dituntut [oleh jaksa] karena memiliki dan menyimpan narkoba; tuduhan ini membawa hukuman minimal lima tahun. Biasanya, para pelanggar akan dituntut [oleh jaksa] setidaknya tujuh tahun penjara" (Hakim 7 dan Hakim 4) 
Kutipan di atas menunjukan keprihatinan para hakim responden bahwa jaksa sering kali mendakwa pelaku dengan narkotika ringan dengan tuntutan lebih berat. Sebaliknya, untuk narkoba dalam jumlah yang lebih besar, jaksa sering kali dituntut dengan ringan. Dalam kondisi seperti itu batas antara menjual dan menggunakan menjadi kabur atau tidak jelas. Tidak jelas apakah kriteria didasarkan pada jumlah obat atau peran pelaku. Dalam situasi ini, penyajian bukti oleh penuntut sering kali bertentangan karena ditemukan setelah sidang pengadilan bahwa para pelanggar didakwa secara berbeda dari yang seharusnya. Akibatnya, praktik diskriminatif kejaksaan menambah tantangan dan masalah bagi penegakan keadilan. Dapat dilihat dari temuan-temuan di atas bahwa hakim menyadari dampak dari keadaan sosial seperti kemiskinan terdakwa dan bagaimana hal ini sering menyebabkan orang menjadi sasaran sistem peradilan pidana dan berakhir di penjara. Dengan demikian, pelanggar narkoba ringan sering kali dianggap sebagai korban dari keadaan mereka.

Dalam kondisi ketimpangan struktural, pengenaan sanksi terhadap pelaku narkoba di bawah umur yang mengalami kerugian sosial ekonomi dapat dengan sendirinya menyoroti masalah-masalah seputar penegakan keadilan. Hakim telah berusaha untuk mengurangi masa hukuman untuk membebaskan pelaku narkoba ringan dari hukuman penjara yang dipersyaratkan oleh UU dan memungkinkan mereka untuk menerima rehabilitasi di luar penjara. Tanggung jawab moral yang dirasakan dari beberapa hakim yang berpartisipasi membentuk presentasi keringanan hukuman yang terbukti dalam praktik-praktik seperti mengabaikan kriteria standar hukuman narkoba. Di Indonesia, pelaku yang secara sosial ekonomi kurang beruntung telah menjadi target sistem peradilan pidana secara tidak proporsional. Mereka dihukum karena keadaan sosial dan ekonomi mereka membuat mereka mudah dikenali, hal ini selanjutnya memudahkan penagkapan terdakwa. Mereka seringkali rentan karena tidak dapat diakui atau ditegakkan haknya di Pengadilan.

\section{Pengaruh Opini Publik dan Media}

Faktor lain yang memperumit penegakan keadilan tampaknya berasal dari opini publik dan penggambaran media tentang hukuman pelanggar narkoba di bawah umur. Meskipun hakim tidak dipilih oleh masyarakat, sejumlah hakim yang menjadi responden menjelaskan bahwa terkadang mereka mempertimbangkan opini publik tentang hukuman kepada terdakwa. Beberapa hakim mengetahui bahwa masyarakat menginginkan pelaku bebas dalam beberapa kasus. Dalam situasi ini, hakim menerima opini publik tersebut, yang menyebabkan terdakwa tidak dihukum. Oleh karena itu, dapat dikatakan bahwa peran opini publik berperan sebagai faktor tambahan bagi ketidakyakinan terhadap fakta. Di Pengadilan, sebagian besar responden (yaitu Hakim 2 dari 10) menunjukkan bahwa harapan publik dipertimbangkan untuk memastikan bahwa hukuman memenuhi harapan masyarakat secara luas: "Jika kami yakin bahwa pelaku adalah murni pengguna narkoba, maka kami akan menghukum mereka sebagai pengguna narkoba. Ini yang diharapkan masyarakat, semoga hukuman kami bisa membantu" (Hakim 7). Setelah keyakinan yudisial memenuhi harapan masyarakat, Hakim 7 berharap hukuman mereka akan membantu pengguna narkoba untuk dapat sembuh jika memang terdakwa tidak terbukti bersalah sebagai pengedar narkoba kelas berat. Oleh karena itu, harapan masyarakat merupakan sumber pengetahuan yang menambah nilai justifikasi pemidanaan. 
Para ahli hukum berpendapat bahwa hukum memiliki moralitas yang tertanam di dalamnya, dan hukum merupakan ekspresi kesepakatan politik tentang apa yang benar dan salah. Dalam mempertimbangkan apakah penafsiran undang-undang akan mencapai keadilan sosial yang berdampak lebih luas, sebagian tergantung pada suasana politik yang menopang kebijakan. Misalnya, anak-anak yang hanya memiliki narkoba dan tidak dapat dipidana dengan kebijakan diskriminasi sosial-ekonomi, maka lebih mungkin untuk dipidana dengan kebijakan kriminalisasi. Dampak keseluruhan dari praktik penegakan hukum (yaitu pemolisian dan praktik penuntutan) tamak sangat tidak adil dalam penyidikan tersebut, di mana polisi tampak selektif dalam menargetkan pelaku narkoba ringan di bawah umur dari latar belakang ekonomi yang lebih miskin dan strata sosial yang rendah.

Ekspektasi masyarakat terhadap dukungan rehabilitatif bagi pelaku narkoba di bawah umur ternyata memfasilitasi munculnya model rehabilitatif. Harapan publik dianggap oleh sebagian kecil hakim responden sebagai sumber pengetahuan yang menambah nilai justifikasi dukungan rehabilitatif.

\section{KESIMPULAN}

Dari hasil analisis penelitian, dapat disimpulkan bahwa dalam memutuskan vonis kasus penyalahgunaan narkoba pelaku di bawah umur hakim dipengaruhi oleh berbagai faktor, diantaranya adalah: 1) Pengaruh Politik. Keinginan para pejabat politik untuk menekan angka penyalahgunaan narkoba menciptakan ketegangan antara melayani agenda politik dan mencari keadilan bagi terdakwa; 2) Pengaruh Penegakan Hukum. Bagaimana polisi mengatur kasus ini mempengaruhi interpretasi yudisial. Hal tersebut dapat dilihat dalam penargetan selektif polisi terhadap individu-individu dari latar belakang sipil dengan strata sosial rendah; dan 3) Pengaruh Opini Publik dan Media. Faktor lain yang mempengaruhi keputusan yudisial berasal dari opini publik dan penggambaran media tentang hukuman pelanggar narkoba di bawah umur.

\section{DAFTAR PUSTAKA}

Azriful, A., Ibrahim, I. A., \& Sulaiman, Y. (2016). Gambaran Pengguna Narkoba Inhalasi (Ngelem) Pada Anak Jalanan di Kota Makassar Tahun 2015. Al-Sihah: The Public Health Science Journal, 8(1).

Gifford, E. J., Eldred, L. M., Sloan, F. A., \& Evans, K. E. (2016). Parental criminal justice involvement and children's involvement with child protective services: do adult drug treatment courts prevent child maltreatment?. Substance use \& misuse, 51(2), 179192.

Handayani, I. (2018). Diversi Penyalagunaan Narkotika terhadap Anak. Sol Justicia, 1(1), 36-41.

Hapsari, I., Soponyono, E., \& Sularto, R. B. (2016). Kebijakan Hukum Pidana Dalam Upaya Penanggulangan Tindak Pidana Narkotika Pelaku Anak. Diponegoro Law Journal, 5(3), 1-14.

Kanang, A. R. (2017). Perspektif Perlindungan Anak di Indonesia. Al-Risalah: Jurnal Ilmu Syariah dan Hukum, 17(1), 1-22. 
Maluccio, A. N., \& Ainsworth, F. (2003). Drug use by parents: A challenge for family reunification practice. Children and Youth Services Review, 25(7), 511-533.

Nainggolan, M., Zahara, E., \& Saparuddin, S. (2010). Peranan Hakim dalam Memberikan Perlindungan Hukum terhadap Anak Korban Penyalahgunaan Narkotika (Studi Pengadilan Negeri Lubuk Pakam). Jurnal Mercatoria, 3(2), 116-132.

Novitasari, D. (2017). Rehabilitasi Terhadap Terhadap Anak Korban Penyalahgunaan Narkoba. Jurnal Hukum Khaira Ummah, 12(4), 917-926.

Sepud, I. M. (2017). Alternatif Penyelesaian Tindak Pidana Narkotika Anak Melalui Diversi. Jurnal Hukum Prioris, 5(3), 276-300.

Simmons, C. W., \& Danker-Feldman, E. (2010). Parental incarceration, termination of parental rights and adoption: A case study of the intersection between the child welfare and criminal justice systems. Justice Policy Journal, 7(2), 1-37.

Soponyono, E. (2016). Kebijakan Hukum Pidana Dalam Upaya Penanggulangan Tindak Pidana Narkotika Oleh Anak Dalam Wilayah Hukum Polda Jateng. Diponegoro Law Journal, 5(2), 1-13.

Stone, N. (2018). Child criminal exploitation: 'County Lines', trafficking and cuckooing. Youth Justice, 18(3), 285-293.

Sukoco, B. (2011). Prospek dan Dilema Penerapan Restoratif Justice System dalam Kasus Pidana Anak. Jurnal Ilmu Hukum, 14(2), 335-346.

Utami, I. R. (2014). Kebijakan Aplikasi Dalam Tindak Pidana Narkotika Yang Dilakukan Oleh Anak Di Pengadilan Negeri Semarang. LAW REFORM, 9(2), 124-138.

Wahyuningsih, U., Khomsan, A., \& Ekawidyani, K. R. (2014). Asupan Zat Gizi, Status Gizi, dan Status Anemia pada Remaja Laki-laki Pengguna Narkoba di Lembaga Pemasyarakatan Anak Pria Tangerang. Jurnal Gizi dan Pangan, 9(1).

Zahra, A., \& Sularto, R. B. (2017). Penerapan Asas Ultimum Remedium Dalam Rangka Perlindungan Anak Pecandu Narkotika. Law Reform, 13(1), 18-27. 